provides the context for the study presented here. Drennan and Quattrin examine the relationship between social inequality and agricultural resources using information on the location of prime agricultural land and settlement distribution in the Valle de la Plata during the first millennium A.D. Their conclusion, which emphasizes the importance of social and political mechanisms over environmental causes, is extremely important.

Antonio Gilman has worked in Spain for a number of years on questions concerned with the rise of hierarchical society. As a Marxist, his perspective is focuses. Gilman-using data collected from the Copper and Bronze Ages in La Mancha-examines the emergence of class stratification, concluding that these inequalities emérge from the competition over areas suitable for intensive farming. reflected in the questions he seeks to answer and the variables on which he

\section{Chapter 6 \\ Chiefly Power and Household Production on the Northwest Coast}

\author{
Kenneth M. Ames
}

\section{INTRODUCTION}

Inequalities may have always existed in human societies, at least at the level of relationships between individuals (e.g., Bender 1989; Olszewski 1991), relationships that are fluid-depending upon the interplay between individual character, age, and gender--since they are structured by social organization, culture, and economy, among other factors (including our biological heritage as terrestrial primates). Why and how do permanent elites grow from this sseedbed? There are two broad classes of materialist answers: elite-as-managers and elite-as-thugs (cf. Gilman 1981). The first category includes Haas's (1982) integrationist school and the second his conflict school.

The elite-as-manager approach sees elites arising from the needs of complex divisions of labor for coordination of tasks, task groups, and information flow. In Service's (1975) classic formulation, emerging elites manage regional specialization in production through redistribution-leading to the formation of chiefdoms. It is clear now that chiefs may do little or no redistribution. The

KENNETH M. AMES - Department of Anthropology, Porland State University, Porland, OreBon 97207.

foundations of Social Inequality, edited by T. Douglas Price and Gary M. Feinman. Plenum Press, New York, 1995. 
absence of any elite-as-manager models in this collection is an indicator of the present status of this approach.

Elites-as-thugs models presently dominate the literature. In these models, some interest group within a society gains control of production, ultimately over labor (Arnold 1991, 1991, 1993, Chapter 3, this volume; Webster 1991) since labor is the ultimate limit on production in nonindustrial economies. This control may be overt and direct, or indirect. The core idea is that elites gain control and reproduce themselves out of their own self-interest. They do not arise from any societal need to coordinate anything-they may do that, but that is not how they come to exist.

Hayden (Chapter 2, this volume) describes societies in which control over production is indirect and fluid, based ultimately on the ability of individuals to manipulate the production of others through debt and contract. In his model, these situations arise, ultimately, where rich environments or highly productive economies permit. The central question becomes, What are the circumstances in which inequality of the kind he and others describe becomes institutionalized and persists irrespective of production levels and of other social and economic changes?

Societies along the Northwest Coast of North America had some form of status distinctions for more than 4,000 years, and elites for at least 3,000 years. The elite developed in concert with significant social and economic changes. Explanations for this evolution easily fall into the managerial or thug categories. Schalk (1977) and Ames $(1981,1985)$ argue that the complex task organization required for taking and preserving large quantities of salmon, coupled with the need to perform other subsistence tasks simultaneously, required economic management leading to the evolution of an elite. Matson (1983, 1985, 1989, 1992) and Coupland (1988) argue that the Northwest Coast's elite developed from the control of resources, either as a consequence of resource ownership itself (Matson) or out of conflict over their control (Coupland) (Ames 1994 reviews these matters and the relevant evidence in detail). To the south, in California, Arnold $(1991,1992)$ holds that chiefs arose among the Channel Island Chumash through their control of specialized production.

The Northwest Coast case is crucial to understanding the evolution of inequality since the coast's eighteenth- and nineteenth-century societies are the world's best examples of complex hunter-gatherers and of hereditary class distinctions among hunter-gatherers. As such, many considerations of the evolution of inequality are directly and indirectly informed by Northwest Coast ethnography. A review of the nature of the Northwest Coast's hereditary elite is essential to continued theory building about the development of elites. In addition to being hunter-gatherers, the societies of the Northwest Coast are examples of stratification in the absence of large polities. As we will see, the household was the polity; there were none beyond the household.
At its heart, this chapter argues that the evolution of social class on the Northwest Coast cannot be understood apart from the evolution of the household economy of the coast's societies (Ames 1985, 1994a; Coupland 1985, 1988). The coast's elites were financed by households. My own recent research has focused on the Northwest Coast household as an instrument of production (Ames i.p.), and some results of that work are incorporated below. However, the elite played out their roles at the village, town, and regional scales. This chapter examines the relationships between production, consumption, and the power of the Northwest Coast's elite class by exploring their roles in production-in controlling it, managing it, and as producers themselves. It considers the power exercised by that elite, and its spatial scale. I agree with Kristiansen (1991) that cultural evolution is as much a spatial process as it is a temporal process (see also Ames 1989, 1991). Finally, this chapter investigates the limits of chiefly power on the coast, asking why coastal societies were not more stratified, why they did not have paramount chiefs similar to those, for example, of Hawaii.

\section{Power}

Central to this chapter is the nature of the power wielded by Northwest Coast chiefs and their kin. Particularly useful here is the distinction between power to, and power over. Cobb (1993:51) defines power to:

Individuals or interest groups may not have the secular means to enforce demands on others in terms of outright wresting surplus from them, but some individuals may wield considerable sway by virue of holding informal offices, belonging to higher status lineages or clans, falling within esteemed age grades, or being male or female.

Power over implies the capacity to "coérce subordinates, including the ability to implement demands through the institutionalization of negative sanctions, ranging from the use of force to jural rights" (Cobb 1993:50). Power over usually comes with power to, but the reverse does not always follow. Hastorff (1990) refines these terms to "power to organize and power over organization." I will argue below, that in the main, Northwest Coast chiefs had power to organize, but not power over organization.

Wolfs scale of power is fundamental to my understanding of power and it is a framework for understanding the power of the coastal elite in the household and beyond the household. He (Wolf 1990:586) describes four modes of power. The first "is power as an attribute of a person"; the second is the capacity of an individual to impose his will upon another; the third is tactical or organizational power in which an actor has the ability to circumscribe or control the acts of others in determinate settings. The fourth mode, 
structural power, is power that structures the political economy; it is power "to deploy and allocate social labor ... [s]tructural power shapes the social field of action as to render some kinds of behavior possible, while making others less possible, or impossible" (Wolf 1990:587).

\section{Embedded Specialists}

Classifications of specialists generally place them into "blue-collar" relationships with elites. Earle's influential model of specialists is an example. He sees specialization as a continuum between "attached" specialists and independent specialists. Attached specialists "produce goods or provide services to a patron, typically either a social elite or a governing institution. Attached specialists are contractually bound to the patrons for whom they work" (Brumfiel and Earle 1987:5; emphasis mine). Independent specialists "produce goods or services for an unspecified demand crowd that varies according to economic, social and political conditions" (Brumfiel and Earle 1987:5). Costin (1991) presents a more complex typology of specialists, with many more parameters than Earle's, but artisans remain in the lower rungs of society. Neither Earle's continuum nor Costin's typology are conceptually adequate to address specialization on the Northwest Coast. Northwest Coast elite individuals may have both contributed to production and controlled production as specialists in the making of important objects such as masks and houses. Earle's continuum requires at least one more pole (changing it from a continuum to a field): "embedded specialists."

Embedded specialists are full- or part-time specialists whose vocation is a part of the household or local economy, and the specialist's activity is integral to the functioning of that economy. Performance is part of the individual's social role defined not on a purely economic or class basis, but on a kinship basis. Embedded specialists are neither contractually bound nor do they produce for a "demand crowd." Embedded specialists may be members of the elite, and making particular elite goods is part of their "power to" and "power over."

\section{THE NORTHWEST COAST}

The Northwest Coast extends from southeast Alaska to northern California (Suttles 1990). Its societies shared a number of features, including stratification, but also differed regionally in how those traits were expressed. For the purposes of this chapter, that diversity will be condensed into two broad regions: the northern Northwest Coast (northern Vancouver Island and the adjacent British Columbia mainland north to include southeast Alaska) and the southern Northwest Coast (south to northern California) (Figure 1).

\section{The Northwest Coast Mode of Production}

Small, autonomous, village-based "local groups" were the basic territorial unit. Most, but not all, of these groups had populations large enough to be biologically self-sufficient, that is, from 180 to 500 individuals (Wobst 1974, 1976). The household or coresidential corporate group (Hayden and Cannon 1982) was the basic unit of both consumption and production. Households were organized into villages and towns. The means of household recruitment and reproduction varied along the coast. There was a fairly strong, genderbased division of labor, which Norton (1985:248) describes as "independent cooperative behavior by both genders" directed to a common end. Moss (1993), however, suggests that the strength (rigidity) of the sexual division of labor has been exaggerated. Slave labor was important. There was what Mitchell and Donald (1988) call a "fair amount of specialization" for huntergatherers.

Salmon (Onchorynchus spp.) were the key resource, because they were storable and occurred abundantly in predictable places, but their importance cannot be taken for granted in every case. Secondary resources were quite significant, as was local resource variation. Though local groups were generally sedentary or semisedentary, on a regional level, patterns of mobility associated with the annual round were quite complex. Resources and resource patches were owned, but ownership patterns varied along the coast (Richardson 1981). A great many resources were stored; preservation and storage were crucial. The relatively short shelf life of stored salmon (ca. six months) was an important limiting factor affecting spring subsistence practices. Creation of wealth was ultimately dependent upon producing food surpluses, though wealth took forms other than food. Redistribution through the potlatch and other means was important. There was a strong ethos against hoarding. Regional systems of exchange and trade were probably important. (The foregoing is based primarily on Mitchell and Donald's [1988] definitive description of the Northwest Coast's mode of production in the eighteenth and nineteenth centuries; see also Ames 1994.)

Households occupied one or more of the large, cedar plank houses that were the primary form of dwelling. Households were generally big, ranging in size from 80 to 150 or more individuals. They owned estates of corporeal and noncorporeal property. In this chapter, these estate-holding households are termed Houses, with a capital $\mathrm{H}$. Corporeal property included resource localities, the ground upon which the House's dwellings were built, the dwell- 


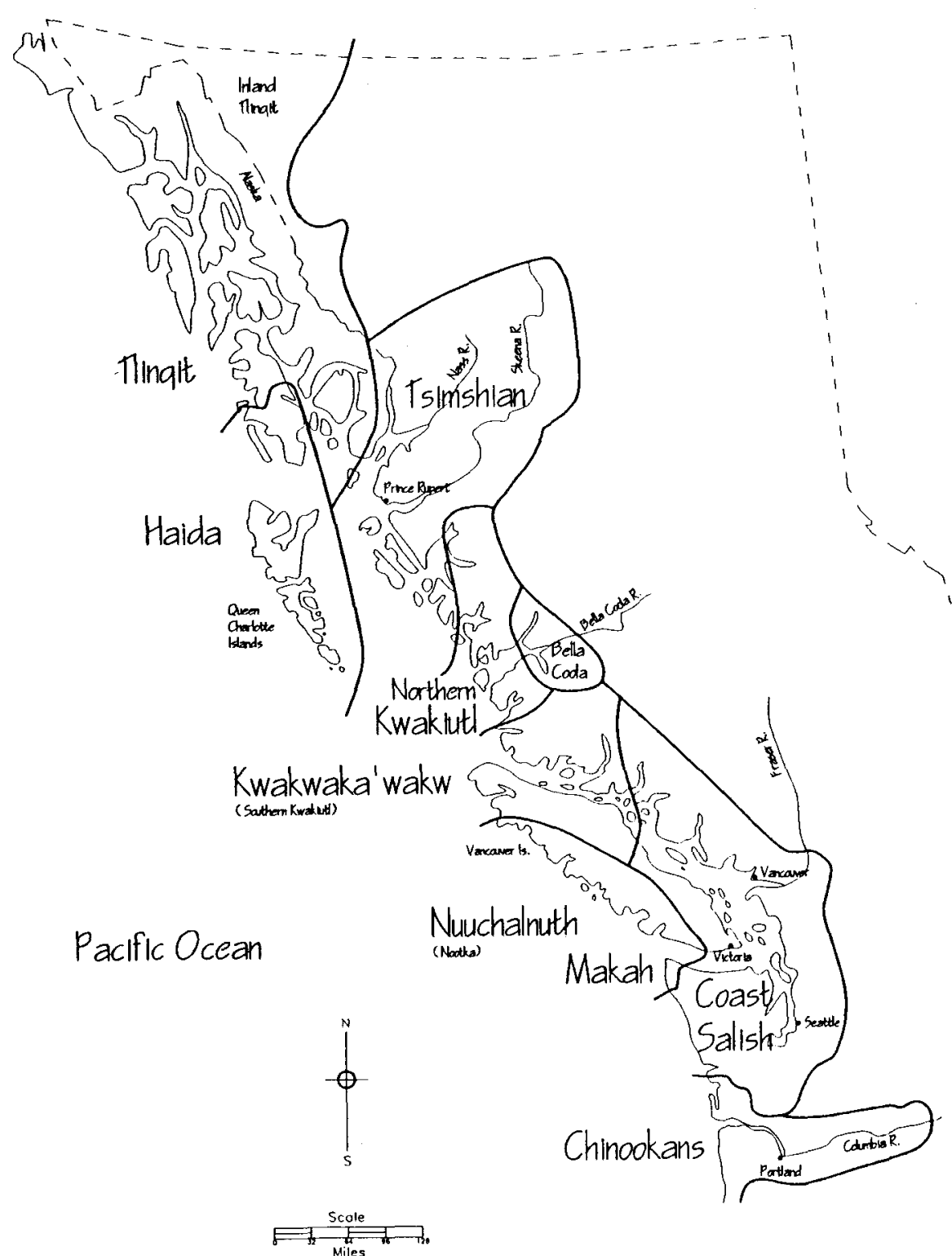

ings themselves, and the processed food and wealth produced by the household; noncorporeal property included the rights to resource localities, to songs and ritual performances, and to particular animal helpers and spirit beings. Noncorporeal property is commonly termed "privileges" in the ethnographic literature. Households had genealogical depth and maintained oral household histories. In theory, at least, household members had equal access to the household's property.

Rectangular surface structures-probably plank houses-appear in the archaeological record of this region between 3200 and 2800 b.p. The earliest occur at the two ends of the coast, in Oregon (Connelly 1992) and northern British Columbia (Coupland 1985).

\section{Social Stratification on the Coast}

Nineteenth-century Northwest Coast societies were stratified. For example, Coast Tsimshian society was divided into two social strata: free and slave. Free people were divided into three classes: smkikét (real people), $i^{\prime}$ qakikét (other people), wa?á?ayin (unhealed people), and slaves (túnkit). Real people include the chiefly families that held the largest number of titles and crests, while other people were titleholders, but holding fewer titles than the smkikét (Halpin and Seguin 1990). Unhealed people held no titles, but were free. The Coast Tsimshian social strata are paralleled among other groups (Kan 1989), and carry implications of a continuum of ritual purity, from chiefs who were pure, through commoners, who were maximally impure. Distinctions between these classes were maintained by marriage within classes and a rule that children of a marriage inherited "rank no higher than that of the lower-ranked parent" (Halpin and Seguin 1990:275). While details varied, this form of social stratification existed all along the Northwest Coast. The elite formed a distinct class because of marriage rules that required a woman to marry a man of equal status, just as slavery was perpetuated because the children of a slave were slaves.

Scale is important here. At the House level, distinctions between the elite and other free members of the household were not always clear cut; free individuals were ranked rather than sharply stratified. The elite become more evident at the level of village or region. Northwest Coast societies also varied in the strength of the rules against marriages and liaisons that crossed class boundaries, and their oral traditions are rich in stories of lovers from the wrong social class.

These distinctions crosscut kin groups, households, towns, regions, even species. In fact, in Northwest Coast oral narratives, chiefs among the salmonpeople and bear-people, as well as other animals, were much more powerful than human chiefs. All Northwest Coast societies, despite differences, had 
some form of this basic set of social strata. Societies varied in how chiefs became chiefs and how sharp were the distinctions between the highestranking elite families and those elite individuals below them. But the very highest ranking families, those from whom chiefs were drawn, usually formed a clearly recognized and distinct group.

Below the highest-ranked individuals were what Drucker (1951) describes as the middle class or, in Coast Tsimshian terms, the other people These families held fewer titles and were usually collateral relatives of the chiefly family, who were direct descendants of the household's founder These lesser titleholders frequently included many of the household's specialists.

Commoners were members of the household by birth, marriage, or choice, but were clearly not titleholders. Many, perhaps all, were clients of the House chief (Adams 1981). These were poor people who had no House. The terms used for such individuals by the native people themselves include "dirty" and "lazy." Commoners could shift their allegiances and join other Houses. People were not bound to their household or local group. Low-status people were not serfs in the sense that they were part of a House's estate though some were hangers-on, rather than members.

The success, wealth, prestige, and long-term strength of a House depended on the productivity of its estate and on the number of members it possessed. The prestige of a House (and therefore of its chief) and its size were directly tied to the ecological productivity of the household's estate, particularly of its salmon resources (Donald and Mitchell 1975). Houses had a certain minimum population size, below which they did not have enough members to perform the basic tasks necessary to reproduce the House (Adams 1973, 1981; Drucker 1951). Commoners and titleholders could be at tracted to and join Houses that were wealthier than their own. Adams (1973, 1981) has argued that if the potlatch redistributed anything, it redistributed population, since potlatches were a measure of the success, health, and wealth of a household group. Chiefs had to work to attract and hold household members.

Northwest Coast societies were stratified rather than ranked societies (as defined by Fried 1967) because of the existence of slaves on the Northwest Coast (Donald 1983, 1985). Donald (1985:242) describes Northwest Coast societies as "class-divided" societies: "class is present and important but does not dominate or determine all social relationships." He distinguished class: divided societies from incipient class societies, where class structure is rudimentary, and from class societies in which class dominates and determines all social relationships. Donald (1985:241) defines class so:

Class is present in a society when significant segments of that society have relatively permanent differential access to resources and/or power. In addition, a class must be capable of reproducing itself biologically. This precludes gender or age categories from being regarded as classes.

Among the two free classes on the coast, kin group affiliation, rather than class, was the source of primary social identity.

Slaves were both labor and wealth (Mitchell 1984). Their labor could be used to produce wealth, but they could also be traded directly for other wealth items. Mitchell describes slave raiding as a means of creating wealth for the raiders. His description is stark: "[T]he free populations of the coast can be seen as analogous to uncaught salmon and uncut trees. And just as the fisherman turned the salmon into food and the woodworker trees into shelter, the predatory warrior converted freeman into wealth" (Mitchell 1984:46).

\section{A History of Northwest Coast Status Distinctions}

It is possible to broadly outline changing status distinctions on the coast over the past few millennia based primarily on evidence from burials. Between ca. 5000 and 1500 b.p., burial practices included inhumation in residential sites, as well as in other occupation sites. This custom ended sometime between 1500 and 1000 b.p. virtually everywhere on the coast. The principle lines of evidence available relating to status currently include grave goods, and the wearing of labrets, or lip plugs. Labrets were worn by high-status women on the North Coast during the contact period; it is clear that labret wear was restricted to a limited number of people for at least 4,000 years on the coast. The archaeological data suggest that gender and region of origin are two major dimensions structuring status on the coast. Definitions of status appear to have undergone at least two major changes during the past five millennia. The data on burial practices are drawn primarily from southern Northwest Coast sites in the Gulf of Georgia region, and from Prince Rupert Harbor in the northern coast (Figure 2) (see Ames 1944b; Beattie 1981; Burley and Knusel 1989; Cybulski 1993).

Labrets

Stone labrets are important evidence for status differences on the coast because wearing them leaves indelible evidence on the teeth (Figure 3) (Cybulski 1993; Murray 1981). Labret wear therefore directly reflects attributes of the living individual rather than postmortem ritual (Figure 4). Labrets only sometimes occur as grave goods. Calculating the frequency of labret wear is made difficult by tooth loss during life and after death, sometimes making it impossible to determine if an individual wore a labret. Cybulski (1993) believes that some of this tooth loss is probably the result of labret wear, but cannot prove it. Matson (1989) speculates that the presence of labrets as grave 


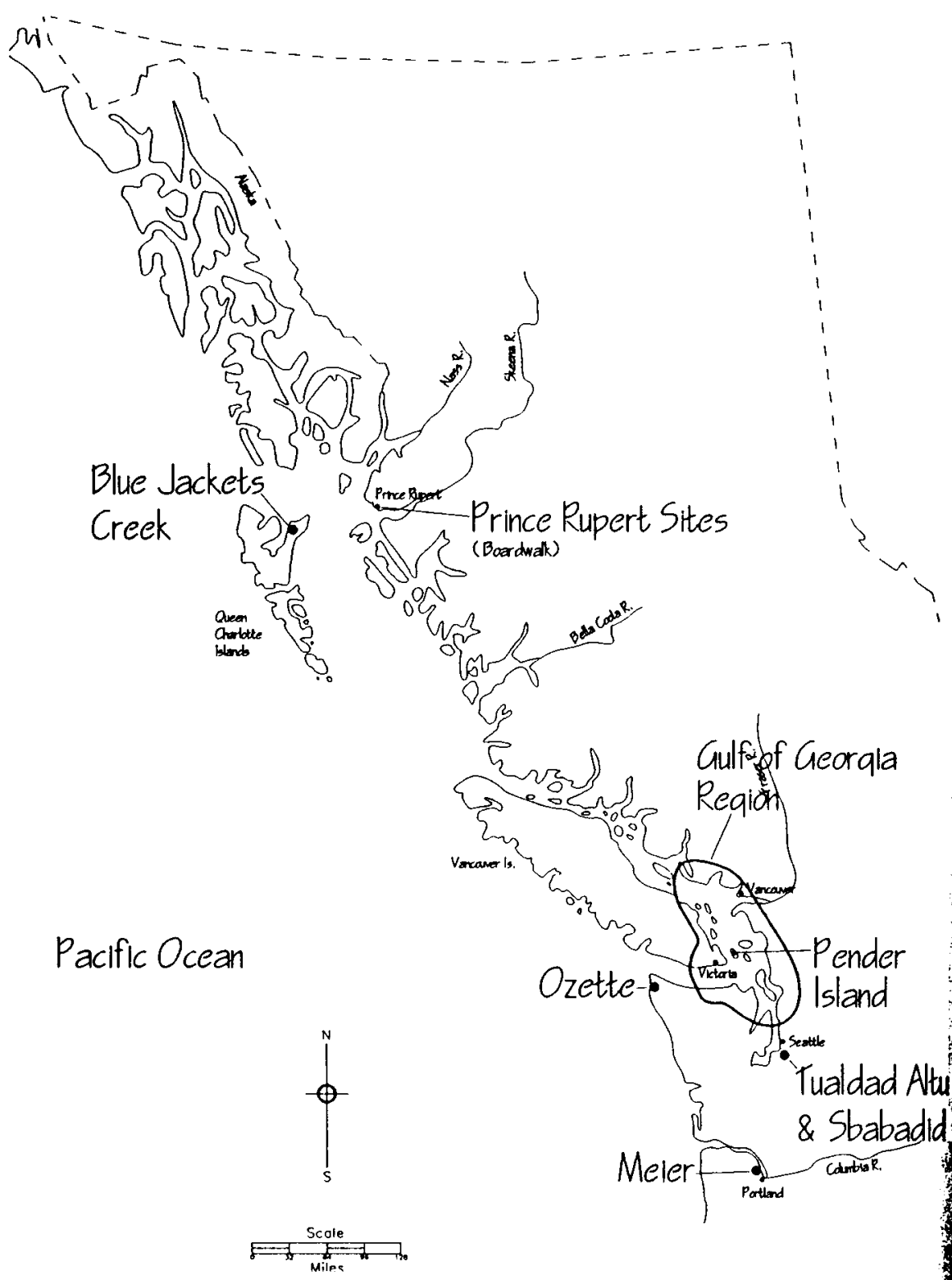

Figure 2. Map of the Northwest Coast showing locations of archaeological regions and sites discussed in the text.
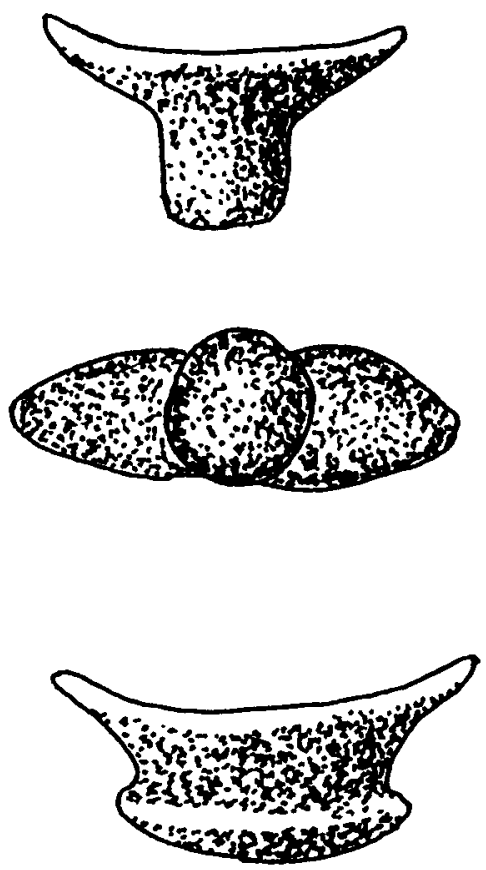

Figure 3. Two types of labrets. The upper is a side view of a labret style sometimes called a "hat-shaped" labret. The middle drawing is a front view of a hat-shaped labret. The lower drawing is a side view of a large "button" labret. The flanges rested against the teeth and the labret body extended through an incision in the lower lip.

goods marks achieved status, and their absence (tooth wear present, no labret) reflects ascribed status, suggesting that with ascribed status, labrets were heirlooms and passed on to the living. This is difficult to demonstrate; labrets occur in a variety of nonmortuary archaeological contexts, curiously enough, often broken.'

Labret wear is found on individuals at two sites predating 3500 b.p.: Pender Island on the southern coast and Blue Jackets Creek on the northern coast. Labret wear appears to have been quite restricted at this time in terms of how many people wore them, but available to both men and women in relatively equal proportions. The wide geographic separation of these two sites suggests this practice was widespread on the coast at this time.

Patterns of labret wear began to diverge markedly between the northern

${ }^{1}$ Curiously, since it is difficult to imagine how labrets could be broken in the normal course of wearing. It seems likely they were being broken before they were discarded, perhaps to maintain the value of labrets as a status marker. 


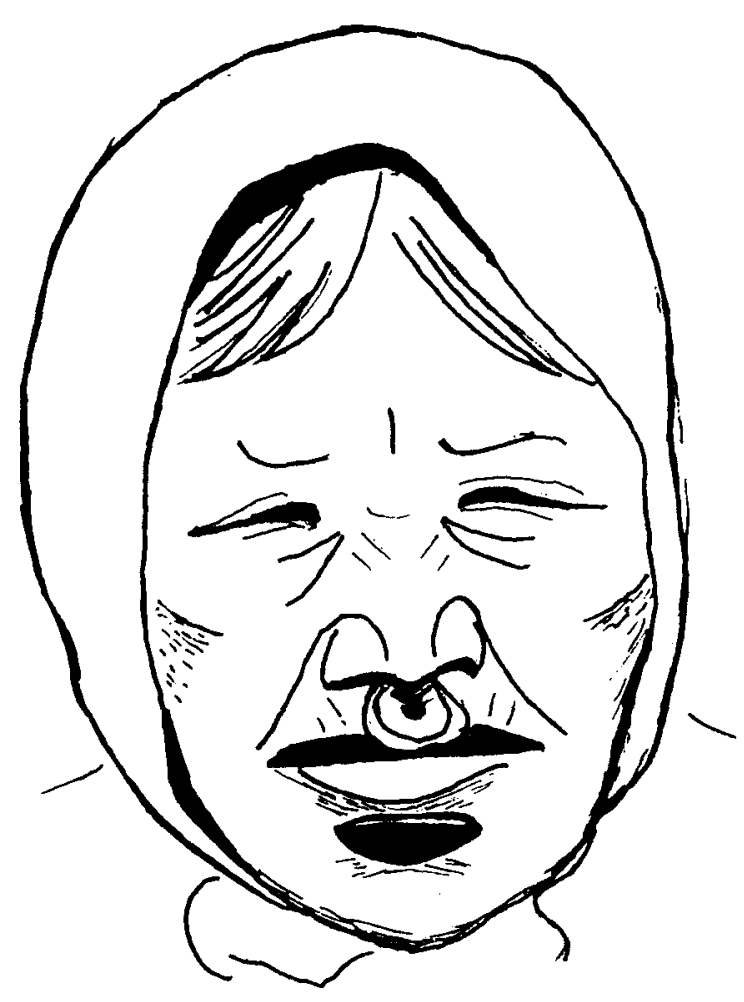

Figure 4. Drawing of an elderly I laida woman ("Queen Johnny of Masset") in 1884 , wearing a labret in her lower lip.

and southern coasts after 3500 b.p. On the northern coast between ca. 3500 and 1500 b.p., labret wear was more common than previously, but they were worn almost exclusively by males. After 1500 b.p., labrets were worn exclusively by females. In contrast, on the southern coast, labret wear appears to have been more common between 3500 and ca. 2000 b.p. then earlier, but worn equally by females and males. After 2000 b.p. or so, the custom ends, being replaced by cranial deformation for both males and females (Beattie 1981; Cybulski 1993). Cranial deformation for high status and free individuals continued on the southern coast until the contact period.

Labret wear is a permanent and highly visible modification of the face, and is an unambiguous status marker-one wears a labret or one does not (Ames 1989). Cranial deformation is only somewhat less unambiguous. The evidence suggests that for the last 4,000 years on the coast it was important to distinguish certain individuals in as clear-cut a fashion as possible. It has also been important to indicate from what region of the coast they originated and to mark gender.

\section{Grave Goods}

Pre-3500 b.p. burials primarily contain items of daily use (Ames 1994b; Burley and Knusel 1989; Severs 1974). Three individuals at Blue Jackets Creek were ochre-stained. Pender Island contains dramatic grave goods. Carlson (1991) recovered 10 horn spoons, several with handles carved in Northwest Coast-style zoomorphic motifs. Some of these spoons rested on or near the jaws of individuals, as though they had been laid across their mouths. Carlson believes this represents a ritual feeding of the dead. The earliest appear to predate 4000 b.p.

Grave goods become relatively widespread and rich after 2500 b.p. along the entire coast. Grave goods include shell-bead necklaces, chipped stone burial blades, copper beads, copper sheets, bone blades, and so on. While the data from the south coast do not suggest site hierarchies, the burial patterns in Prince Rupert Harbor raise the possibility of a site hierarchy (Ames 1994b) there. The richest burials and occupational debris occur at the Boardwalk site in the harbor. Other, contemporary sites are generally similar to Boardwalk, but lack copper and other exotic items.

The mortuary patterns are actually more complex than this summary suggests, because differences between burials extend to the presence or absence of boxes (as coffins), stone cairns, the use of sea otter teeth as decorative studs on boxes, dog burials, human trophy skulls, and so forth. It is quite clear, however, that during this period there are significant differences between graves in terms of the wealth of the accompanying grave goods.

Gender is a major dimension structuring burial practices, particularly in the north. In the south during this period (3500 to 1500 b.p.), there does not appear to be a significant gender bias in the distribution of grave goods, nor in the numbers of males and females recovered. There is a strong male bias in the north, in the number of interments with grave goods, in the kinds of grave goods, and in the sex ratios of the interred. Males significantly outnumber females (1.86 males: 1 female). This particular bias may extend throughout the prehistoric burial record of the northern coast.

After ca. 1500 b.p. interments in residential sites virtually cease in both regions. The most recent such burial complex on the coast is the Greenville burial ground on the northern coast, dating between 1600 and 500 b.p., though most burials predate 1000 b.p. (Cybulski 1993). With the exception of burial boxes, some dog remains, and elderberry, ${ }^{2}$ the Greenville graves lack grave goods of the kind so common earlier.

${ }^{2}$ In Tsimshian oral tradition, elderberries are linked to human mortality 
Slavery

The evidence for the antiquity of slavery is ambiguous. Cybulski suggests that the sex ratios ( 1.87 males: 1 female) for the Prince Rupert Harbor burials may indicate slavery. Historically, slaves' corpses were disposed of casually, even thrown into the surf. If a significant portion of Prince Rupert Harbor's ancient population were female slaves and their bodies were similarly treated, the skewed sex ratio would result. This reasoning would suggest that slavery existed on the Queen Charlotte Islands around 4000 b.p., given the sex ratio for the Blue Jackets Creek burials. ${ }^{3}$ One must also conclude that in the south slavery played a minor role at this time, and was more likely to involve males (given the generally higher numbers of females in southern coast burial populations, which have an overall sex ratio of 1.08 males: 1 female), an interesting possibility. A south coast sample of 34 burials predating 2500 b.p. does have a sex ratio of 1.44 males: 1 female, a ratio that after 2500 falls to $.98: 1$ (data from Cybulski 1993). This would imply an early reliance on female slaves. 'This argument also implies that at least a quarter of the Prince Rupert Harbor's free female population had been enslaved and taken elsewhere. I do not think that Cybulski's hypothesis can sustain all this inferential weight without additional supporting evidence.

The evidence is clear for raiding in Prince Rupert Harbor at this time. Several individuals appear to have been found and decapitated. Middle-aged females are the most common victims (Cybulski 1979). Other individuals were found in what Cybulski (1979) calls "unconventional" burial postures. Most burials are flexed; these unconventional ones are quite loosely extended (most of these predate 3500 b.p.). These data could be read in two ways as evidence for slavery. The bound individuals were killed in the course of raids as not being worth enslaving, or, alternatively, they were slaves who were killed as part of ritual disposition of wealth. These inferences remain speculative, however. On the southern coast, the skeletons of scalped females predating 2200 b.p. have been recovered, suggesting the existence of slavery to the investigators (ARCAS 1991).

\section{Contemporary Events}

The widespread presence of wealthy graves by 2500 b.p. is somewhat later than evidence for several major shifts on the coast: (1) the development

${ }^{3}$ The Blue Jackets Creek material was originally examined by Murray (1973), whose results differ from Cybulski's. Murray identified 8 males and 9 females for a sex ratio of .9:1. Cybulski identified 13 males and 6 females for a ratio of 2.6:1. Cybulski cannot account for the different results. Blue Jackets' small sample size predudes placing much inferential weight on these patterns. of heavy reliance on stored salmon (Ames 1991, 1994 and citations therein; Matson 1992 and citations), (2) the appearance of plank house villages (Ames 1991, 1994), and (3) warfare in the north (Cybulski 1975); Mitchell (1988) suggests that the elaboration of burials in the south was also due to increased levels of warfare, but he has no direct evidence.

The second change in how status was marked on the coast occurred between ca. 2000 and 1000 b.p. This change seems to be part of the broader shift in funerary ritual marked by the end of subsurface interments. In the north, these changes may be related to evidence of an expansion in warfare (Maschner 1991; Moss and Erlandson 1992) and shifting tribal distributions (Wooley and Haggarty 1989). A number of investigators have independently argued that during this period the large chiefly houses of the historic period appear, as well as multi-House villages (Acheson 1991; Coupland i.p.; Maschner 1991, 1992), though this is as yet unproven. The evidence for the south is in some ways more subtle but, in addition to the changing burial customs, includes an apparent change in the production of art and in subsistence technology, and an increase in warfare (Fladmark 1982). It may also be accompanied by the appearance of houses of enormous size (Ames 1991), though that remains to be demonstrated (Ames i.p.).

\section{The Power and Functions of Northwest Coast Chiefs}

Household chief was the basic, elite office everywhere on the coast. All chiefs were House chiefs, regardless of what other chiefly offices they might hold. House chiefs were usually drawn from the highest-ranking family in the House though, in practice, rules of succession were flexible. Individuals, including commoners, could found new Houses. Levels of chief above the House chief existed on the central and northern coast, but not on the southern coast among the Coast Salish. Among the Coast and Southern Tsimshian, the chief of the highest-ranked House (matrilineage) in a town was town chief. There are four Tsimshian matriclans and a clan's highest-ranked lineage chief was clan chief, and the tribal chief was the highest-ranked clan chief. A Haida town chief was the chief of the House or lineage segment that owned the town site itself. Among the Nuuchalnulth, whose local groups were tied together into confederacies, the highest-ranked town chief was confederacy chief.

There were also Great Chiefs, chiefs of remarkable social stature who could organize large raiding expeditions, command tribute, or have influence over several villages. Great Chief was not a formally recognized status; the term has been invented by anthropologists. Generally, Northwest Coast people did not rank chiefs linguistically, usually having only one term (e.g., Drucker 1951). For de Laguna (1983), Great Chiefs were a result of the fur trade that began in the late eighteenth century, but Stearns (1984) and 
Garfield (1939) think they predate contact among the Haida and Tsimshian. Stearns suggests they existed among the Haida at first contact with Europeans and represent a precontact phenomenon, while Garfield suggests the office (which she terms tribal chief) developed among the Coast Tsimshian only a century or so before European contact and as a consequence of changes in Coast Tsimshian settlement patterns. The most famous Great Chiefs include Maquinna among the Nuuchalnulth, and Legax among the Coast Tsimshian. Maquinna may have "controlled" some 10,000 people (Penthick 1979), and both chiefs dominated trade in their respective regions

House chiefs managed their House's estates. Stearns (1984) distinguishes between instrumental power and expressive power exercised by Haida chiefs. Chiefs exercised instrumental power over the House's physical resources, and expressive power over the House's noncorporeal estate. An important aspect of instrumental power lay in the chief granting permission to non-House individuals to hunt, fish, or gather at resource localities that were owned by the House. Permission was always, or almost always, granted. Not asking, however, was a deep affront that could lead to a blood feud. Nuuchalnulth chiefs were given tribute in return for this permission (Drucker 1951). Chiefs declared major resource seasons open, and decided the timing of seasonal residential moves. They organized raids and wars.

There was either variation along the coast in the power chicfs held with regard to their household's resources and territories, or in how various observers have interpreted and described that power. On the one hand, many (e.g., Stearns 1984) describe the chief as managing the House's estates, but the estates (including rights and privileges) belonging ultimately to the House. Theoretically, a House's estate belonged to all members of the house, but chiefs usually treated the House's noncorporeal property as though it were their own. Drucker (1951), on the other hand, describes the estates as belonging to the Nuuchalnulth chiefs: all the titleholders of a household group owned rights to some resources, territory, and the like, and these rights were theirs, not household property. Richardson (1981), reviewing evidence for resource ownership on the coast, concludes that Nuuchalnulth chiefs held rights to resources in trust for their house, and did not own them. He suggests that only Coast Tsimshian chiefs held rights to resources apart from their House's estate; however, I am not sure I agree with his reading of the appropriate passages in Garfield (1939). Caution is necessary in making inferences about resource ownership based on normative descriptions of Northwest Coast practices. Riches (1979:151) states that individuals among the Coast Salish and Chinookans owned resources. Suttles (1968) places individual ownership among central Coast Salish in this context in quotation marks. Richardson shows that among the southern Coast Salish and Chinookans a few key resources were controlled by the community, not by in- dividuals or families, while among the more northerly central Coast Salish crucial resources were controlled by extended families. There was considerable variation around the theme of resource ownership.

Further, what was owned varied. In some cases, everything within an owned patch was controlled; in other instances ownership actually included only rights to exploit a particular resource and all other resources in the patch were part of the commons. The owned resources were not inevitably essential to group survival (e.g., Suttles 1951).

Expressive powers involved displays of crests and performances of songs, dances, and narratives, and of spirit powers. Chiefs could be shamans, but not necessarily. In the north, their spirit powers were related to, but different than, shamanic power (e.g., Guedon 1984). Organizing and participating in the public rituals in which the House's privileges were shown was a central part of the chiefs job. The continued stature and prestige of the House depended on his taking part in potlatches and/or other public rituals. The activities of chiefs "above" Haida House chiefs were primarily expressive or ceremonial. Coast Tsimshian tribal chiefs, in contrast, could call on all the young men of their group to do their bidding and could field war parties against opposition (Garfield 1939). Nuuchalnulth chiefs above the household also wielded considerable instrumental power.

In spite of their power, chiefs everywhere on the coast had to seek advice from councils, whatever their stature. Stearns notes that the power of Haida town chiefs was dependent on the power and support of the town's House chiefs. House chiefs also had councils.

It is evident from the ethnographies that while chiefs enjoyed considerable authority and prestige, they had little direct power over free individuals. The Tlingit paid little attention to their chiefs (Emmons 1991). Mitchell (1983), in his all-too-brief study of the power of Legax, the early nineteenth-century Tsimshian Great Chief, concludes that Legax had little or no direct power over other Coast Tsimshian individuals or groups within his tribe (in sharp contrast to Garfield's conclusions). The powers of Northwest Coast chiefs present a conundrum: they appear powerful, but what power did they actually exercise?

While a Legax could muster the resources of the chiefs below him (clan and lineage) for a potlatch, he had no control over their House's estates; he could neither tell another Tsimshian what to do nor could he coerce him. House chiefs had the power to wage war, to conduct trade, to permit outsiders to use resources belonging to the House's estate, to declare the fishing or hunting seasons open, and to display the House's privileges. There seems little evidence that they had power over the estate or their fellow House members. I can find only one case where chiefs appear to have exercised power over House members and resources. Chinookan chiefs and elite individuals may have had the power to seize the food of lower-status individuals, 
apparently causing occasional famines (Ray 1938). Chinookan chiefs could apparently take anything they wanted; Ray (1938) noted that they were more powerful than chiefs elsewhere on the coast

Many early European voyagers observed, for example, that while chiefs attempted to formally control trade between the ships and their people, everyone traded. Their powers were circumscribed by the existences of councils, by rivals for their status, by the ability of members of their House to join other Houses, or even to establish new ones, and by their strong need, therefore, to hold their followers. They did have wealth. They also had power over slaves. Before turning to slaves there is one other important element of chiefs' power to discuss, and that is its spatial scale.

The instrumental base of chiefs' power was their House's estate. Powerful Houses and chiefs were so because, ultimately, their estates had rich, productive resources that attracted people to join the House (Adams 1973, 1981; Ames 1981; Donald and Mitchell 1975). In Haida towns, sometimes the town chief (whose lineage owned the townsite as part of its estate) was weaker than a House chief whose House had a richer resource base and more people. However, chiefs operated on a larger spatial scale than their household's territorial estate or the town in which they resided. The village or town was the basic stage for political activities (Stearns 1984), but Houses, and therefore their chiefs, were linked through potlatch and marriage ties to several towns or households scattered over fairly large areas. Adams (1981) asserts that at this regional scale, chiefs formed a ruling oligarchy. Extensive potlatching linkages created a kind of international politics (in Adams's terms), so that the field of political behavior extended well beyond the village (Adams 1981). The northern and southern coasts, as regions, probably represent the maximum size of these linkages, as each was probably an interaction sphere (Ames 1989; Suttles 1990). However, it is doubtful that these regional networks or interaction spheres can be construed as polities, anymore than can towns or villages. The House was the political unit on the coast. In this context, it is worth noting that slaves were drawn from an enormous territory.

Chiefs owned their slaves, and could do as they desired with them, including killing them as part of potlatches and other important events. The wealth of chiefs, the resources they accumulated and gave away through potlatching, depended on slave labor (Donald 1983, 1985). Since slaves did not exist socially, they were not subject to any strictures imposed by the division of labor (Donald 1985). Having no gender-socially-they could do any tasks, no matter their biological sex. Slaves were people who, by their capture (most slaves were war captives, though chiefs traded for them as well), had been stripped of whatever social personae they possessed and lived in a state of social nakedness.
In sum, chiefs were firmly rooted in their households or territories, and all chiefs were first of all household chiefs. A House's prestige, and therefore that of its chief, rested on the productivity of the household's estate, and on the ability of the household's chief to operate in the larger arena in which the prestige of individual chiefs was measured. Typically chiefs could only command the production of their own household. Chiefs had extensive power to use the resources of their House's estate, but there seems little evidence to suggest that, as a class, chiefs had direct power over free individuals. They had tremendous authority and, with the right personality, might become autocrats (Boas 1916). On the other hand, people frequently paid no attention to them. Chiefly power was limited by the existence of councils and the need to gain councilors' support. It was also limited by the possibility that other members of the House could establish their own House (Stearns 1984). Chiefs owned slaves, and may have depended on them to procure the resources they needed to participate in the regional systems of potlatching and ritual. Slaves and their labor were the only resource over which chiefs exercised clear unambiguous power. Otherwise, coastal chiefs had a great deal of power to, but had rather limited power over.

\section{Chiefs, Household Production, and Embedded Specialists}

\section{Chiefly Labor}

Chiefs appear to have been directly involved in production, but it is not clear to what extent or in what ways. The ethnographic data on the role of House chiefs and elite individuals in daily subsistence production are mixed, making it difficult to establish the extent to which chiefs and their immediate families (as opposed to all high-ranking individuals) actually hunted, fished, gathered shell fish, and the like. According to Oberg (1973), Tlingit chiefs were not supposed to perform tasks of this kind. Drucker's (1951) account of Nuuchalnulth chiefs is similar-they did not do daily tasks. However, Huelsbeck (1989) argues that whaling and sea mammal hunting by Nuuchalnulth chiefs was economically important to their households. Boas (1916) states that Tsimshian chiefs were supposed to be expert in all activities and Princes were expected to be excellent hunters. Barnett (1955) suggests that the participation of Coast Salish chiefs in daily subsistence activities was a matter of their own choice. Apparently, however, chiefs did receive food from their House members whether they hunted or fished or not. It is unlikely-given the population of most Houses, and the rather large numbers of all titleholders in any house-that elite individuals who were not members of the current chief's family could avoid daily tasks. In any case, it may be in the areas 
of slave raiding and specialized production that the labor of the elite was crucial to household reproduction.

\section{Slavery}

Slave labor was the only labor directly controlled by Northwest Coast chiefs. The products of their labor contributed to the general pool, but could be appropriated by the chief who owned them. Mitchell's (1985) estimates of the number of slaves present in the different societies along the coast range from $2 \%$ and $3 \%$ to almost $30 \%$ of some groups. Since they were acquired through warfare or trade by chiefs, slaves were a major contribution by chiefs to the House's economy. In addition to standing outside the sexual division of labor so their labor could be employed for any task, slaves also may have provided a means of solving short-term labor bottlenecks (Bogucki 1993) Labor bottlenecks would arise when complex simultaneous tasks Wilk and Rathje 1982) required many hands, but only a few were available. Slaves could be acquired, used, and disposed of or traded all in short order.

\section{Specialists}

In Northwest Coast Houses, embedded specialists did things necessary for the economic and social reproduction of the household. They appear to have been members of their House by birth, their specialization an inherited trade; they may or may not have been members of the chiefly elite, though they held titles (Drucker's middle class). Such specialists could also be hired by other Houses, usually by chiefs. The crucial point here is that when they were part of the elite, they produced elite goods, not as dependents of an elite class, but as part of their roles as elite individuals.

It is difficult to establish how many tasks were performed by specialists. Most ethnographies mention wood-carvers and painters who sometimes supported their families on commissions from the elite. Canoe making may have been another embedded specialty. Boas (1916) implies it was associated with high status. He also indicates that there was village-level specialization in production of food and prestige objects among the Coast Tsimshian (Allaire 1984). Specialization appears to have been inherited and widespread for both women and men. There is no evidence suggesting that chiefs could coerce the production of specialists.

For the Northwest Coast, woodworking and wood carving provide the clearest examples of embedded specialization. The most famous woodworking specialists on the Northwest Coast are carvers, but there were a number of other specialists in wood. On the southern coast, embedded specialists included plank makers who made the wide, cedar planks with which houses were walled (Mauger 1978). Wood carving, however, appears to have been primarily a high-status or elite specialty (though anyone could carve, including slaves). There are a number of lines of evidence to support this.

Among the Coast Tsimshian, some carvers were members of the gitsonkt (Shane 1984). 'The word gitsonkt is from the Coast Tsimshian word gidson meaning "inner or secret room." The gitsonkt carved masks and made mechanical devices used in naxnoq performances by members of the Coast Tsimshian elite, particularly chiefs. These performances related to important spirit powers possessed by chiefs as part of their expressive powers (Guedon 1984) The institution was not limited to the Tsimshian, existing among at least the Northern Kwakiutl. In addition to carving, the gitsonkt were a secret council of advisors to their chiefs, hence their name. Their methods for carving and making the devices were secret, and the punishment for discovering or revealing these secrets was death. Thus, production and use of certain critical privileges was tightly controlled and restricted.

Many of these individuals were of high or chiefly status; before contact the gitsonkt may have always had high status (Shane 1984). High-status individuals also carved other objects related to the prestige and crest systems One of the most famous of these is the "rain screen" that stood at the back of the Whale House in the Yakutat Tlingit town of Klukwan. The screen was carved either by two commissioned Tsimshian carvers, or by two Tlingit House chiefs: Kate-su, who built the Whale House during the 1830 s and carved the screen, and his later successor, Skeet-lah-ka, who painted it (Emmons 1991:64).

Before the introduction of iron and steel, stone adze blades of nephrite were the primary hard, sharp, wood-carving tool. Nephrite is rare on the coast and the adze blades were widely traded. Archaeologically, these items are often reworked and resharpened down to exhaustion. Nephrite adzes were worth one or two slaves among the Tlingit (Emmons 1991). Thus only slave holders-elite individuals-could purchase them.

Good carvers and painters were commonly hired. They and their families lived in the house of the chief who commissioned them for the project's duration. In this case, the relationship between carver and client approximates Earle's concept of attached specialists. However, the contractual relationship lasted only for the life of the project, after which the carver moved on. Further, if the carver was of high status, then the relationship was not one between patron and dependent, but between social equals. Famous carvers appear to have called their own tune.

The possibility that elite individuals functioned as embedded specialists is not limited to the Northwest Coast. Recent evidence from Copan and other 
late Classic Maya sites suggests that scribes and sculptors (who made the stelae) were members of the elite, not of the upper levels from which Kings were drawn, but elite nonetheless (Hammond 1991).

\section{Gender}

Both men and women held high rank; both men and women could wield chiefly power and influence. Norton (1985) reviews the debate over how commonly women formally and informally exercised such power. Women's production was central to the house for both household consumption and exchange and trade. Norton (1985) argues that during the colonial period at least, women's products set coastal standards of value. The archaeological data clearly indicate that gender was a central dimension of high status for the last 2,500 years. The interplay between gender and burial ritual was much more subtle than indicated above (Ames 1994b), but a full discussion is beyond the scope of this chapter.

\section{The Role of Chiefs/Elites in Household Production in the Archaeological Record}

Household Production

There are four sets of excavated structures with sufficient exposures to be useful here. All are in the southern subarea: Tualdad Altu near Seattle, Washington; Sbabadid, also near Seattle (Chatters 1989); Meier, near Portland, Oregon (Ames et al. 1992); and the famous Ozette site, on Washington's Olympic Peninsula (Huelsbeck 1989, Samuels 1989). Sbabadid was a plank house dating between A.D. 1790 and 1825 (Chatters 1989). Artifact distributions within the house indicate the presence of a harpooner; debris distributions suggest specialization in working copper, bone, and lithics.

At Ozette, a Makah (culturally related to Nuuchalnulth) village on the northwest tip of Washington's Olympic Peninsula dating to ca. 250 b.p., one high-status and two lower-status houses were sampled (Samuels 1989). Within the high-status house (House 1), the evidence suggests that chiefly status families (1) may have worked less at daily tasks than other residents, (2) hosted feasts, (3) participated in whaling as harpooners, and (4) controlled access to valuables. Contrasts between houses indicate that the high-status household had access to high-status foods, such as whales and preferred shellfish beds. As noted above, Huelsbeck (1988) argues that sea mammal hunting by high-status individuals was an important contribution to the household economy.

The Meier site was occupied between ca. A.D. 1400 and ca. 1830 and is located within historic Middle Chinookan territory. The excavations exposed a single, large house $14 \mathrm{~m}$ wide and $28 \mathrm{~m}$ to $32 \mathrm{~m}$ long, representing some 44,000 to 75,000 board feet of lumber (the equivalent of four to seven modern, North American single-family dwellings). The house was used and rebuilt over 400 years, requiring something on the order of 400,000 to $1,100,000$ board feet (figures are based on Ames et al. [1992], Ames [i.p.]), or between 40 and 110 modern houses - a large housing tract. The precontact permanent population of Middle Chinookan territory was at least between 3,000 and 6,000 people (Boyd 1985). If the Meier house was home to perhaps 80 individuals, one can easily calculate the total requirements for wood for structures alone. The house itself was a major focus for household labor. The household's elite lived in its northern end, as indicated by the distribution of wealth and prestige markers. Bulk food processing (butchering, roasting) occurred in the south end. Interestingly, shellfish may have been processed in the high-status end. In addition to prestige markers, a range of valuable equipment (nets, guns, metal-tipped arrows and spears, and heavy stone toois such as mauls) was cached or stored in the north, or high-status end. In general, tools with high labor costs are concentrated in the north end. Three stone adzes (two of nephrite) were associated with the same hearth in the northern third of the house (in contrast to antler-splitting wedges, which are ubiquitous in the deposits). Ethnohistoric evidence suggests that members of the same extended family shared a common hearth within these large structures. The evidence from Meier indicates elite control of some aspects of the means of production, including guns, nets, and metal tools, and over access to prized trade goods, including elite markers (European uniforms) and tools (iron projectile points). The evidence may also indicate direct involvement of elite family members in subsistence production. Freshwater mussel processing features are concentrated in the house's north end, for example, and the presence of nets suggests the people at the north end may have done the fishing. Elite individuals may also have been woodworkers or carvers (recall the construction requirements for wood).

Tualdad Altu is the oldest of these excavated south coast structures; its uppermost deposits date to A.D. 400 to 500 . Chatters (1989) found sharp differences between the west and east ends of the structure in subsistence and fabricating tools and in some classes of mammal and fish remains, suggesting some specialization in hunting large terrestrial predators and sea mammals, and in net making.

\section{Specialization}

Copper objects recovered from graves in Prince Rupert Harbor, dating as early as 2300 b.p., may be the earliest evidence of production specialization on 
the coast (Coutre 1975; Ames 1994b). Coutre (1975) suggests that the workmanship required some level of specialization and perhaps mass production.

An anthropomorphic handle is the earliest wood-carving tool from the coast; it dates between 3800 and 4200 b.p. (Matson 1976). The zoomorphic spoon handles recovered from Pender Island are contemporary and older than the handle, are well executed, and display basic features of the Northwest Coast ant style. Traditional Northwest Coast woodworking skills existed by 3500 b.p., indicated by the presence of stone adzes of many sizes, and wooden burial boxes (Cybulski 1993). It is possible that large freight canoes existed by this time as well, but they certainly existed by 2200 b.p. (Ames $1994 \mathrm{a}$,b). There is evidence from Prince Rupert Harbor for a possible specialized woodworking site (Ames 1994b) dating between 3500 and 1500 b.p.

\section{SUMMARY AND CONCLUSIONS}

Nineteenth-century Northwest Coast chiefs had considerable power to organize production, public ceremonial, and ritual. They had the power-and obligation-to accumulate and display the wealth employed for potlatching. This power is balanced by their lack of power over free individuals and the limits imposed on their power by councils, and by the ability of household members to vote with their feet by leaving the household, or even to establish a new House.

This does not mean, however, that chiefs did not exercise tactical power over production and over the organization of production at the household scale or larger. The Meier site data indicate that elite members of that household may have controlled access to crucial tackle and equipment, including nets and guns. At Ozette, elite individuals appear to have been harpooners, perhaps controlling the production of crucial offshore resources. Equivalent evidence unfortunately does not yet exist for other portions of the coast. High-status individuals at Ozette may not have been otherwise involved in daily economic activities. Chiefs also affected production through slaves and as embedded specialists

Nineteenth-century Nuuchalnulth chiefs, and, by implication, all Northwest Coast chiefs, depended on slave labor to produce the wealth required for potlatching (Donald 1983, 1985). But slaves also contributed labor to the House itself as extra hands, particularly during periods of labor bottlenecks. Of course, slaving could have created or exacerbated those bottlenecks when raiders carried off household members. Chiefs also had houseless commoners as clients who, though free, were at the very bottom of the social ladder (slaves were not on the ladder). Their labor could also be commanded. Interestingly, there are no accounts of chiefs diverting slave labor into overtly "thug" direc- tions - no slave bodyguards to enforce a chief's will, for example. But, if a chief did behave in that way, the rest of the household could leave. The antiquity of slavery on the coast is difficult to establish. It could have begun as early as ca. 3000 to 2500 b.p., at about the same time that plank houses, villages, and elaborate social distinctions appear in the record.

Titleholders may have also exercised tactical control over production as embedded specialists. This control may have been exercised in two ways. In the first, titleholders themselves may have produced many of the masks and other objects crucial to the display of household privileges as part of their power to, and if, as among the gitsonkt, they were the only ones who could make the object, as part of their power over the noncorporeal portion of the household's estate. Titleholders also commissioned carvings. They appear to have been the only House members with the wealth to acquire crucial equipment, such as nephrite adzes and, during the colonial period, steel. Finally, as both producers and consumers of carvings, elite specialists could set the standards against which the work of other, lower-ranked, or even slave, artisans could be measured.

The second form of tactical control involves the House itself and other major tools, such as canoes. The House was a major focus of labor and skill, and the household's primary instrument of production (Ames i.p.; Suttles 1968). The household owned its House, even in areas where ownership of resources was diffuse (Suttles 1968). Northwest Coast houses may have had use-lives of up to several hundred years. The family or line that controlled or owned such a house could exert enormous influence over the rest of the household, without that influence necessarily having to be overt on a daily basis. On the northern coast, the name borne by a House chief was also the name of the House and of its house, clearly showing the tie between chiefly status, the physical dwelling, and the corporate human group. The archaeological data from the Meier site suggest woodworking was associated with high status. Boas (1916) indicates that canoe making was a skill associated with princes-young members of elite families. It is possible then that Northwest Coast chiefly and higher-status families monopolized certain crucial skills that were central to household economic production, to its ritual and ceremonial functions, and to the construction and maintenance of the House's house.

The control exercised by chiefs over natural resources apparently varied along the coast, as did the importance of the resources so controlled. In only one case (the Chinookans) is there evidence of elite individuals taking food from the mouths of lower-status people.

It is not clear that Northwest Coast chiefs had strategic power as defined by Wolf (1990:586). The power of Great Chiefs seems decidedly slippery; they had wealth, and great power to organize. It may have been their power to 
organize at a regional scale that represents their strategic power. Otherwise, strategic power may have rested more with the chiefly oligarchy than with any individual, but that is hard to determine.

Northwest Coast chiefs had their feet planted firmly on both sides of a major contradiction. On the one hand their position depended on their place within the household, on their ability to "manage" the House's estate, on their control-both quite indirect and direct - of certain key aspects of production, perhaps including fundamental craft skills, and their continued ability to cajole, manipulate, and wheedle their household into doing what they, the chiefs, wanted them to do. On the other hand, their position depended on a steady supply of slave labor, stolen from outside the House. It is this contradiction that produces the competing views of Northwest Coast chiefs as managers or thugs.

All chiefs were ultimately House chiefs even though they functioned at the town and regional level. This is a second contradiction at the heart of Northwest Coast chiefship. I can find no evidence that any chief ever completely transcended his House and expanded his power base to include several houses or even one village, to the extent that a chief could be said to have exercised the same kind of power over an entire community, as he did over his House, such as, for example, a Hawaiian paramount chief could. Great Chiefs had great wealth and the ability to influence events in many Houses, perhaps even many villages, but no power over them.

There is archaeological evidence for elites on the Northwest Coast for at least the last 2500 to 3000 years. It is unimaginable to me that some elite individuals did not attempt to extend their reach beyond their House. The tantalizing hints of site hierarchies noted above may be archaeological evidence of such experiments in polity building. Why did they fail? Or never occur?

It was not because these people were hunter-gatherers or had low pop ulation densities. Tremendous wealth was available as a result of their economy. Ethnographically it was dispersed among many Houses, but if one individual, or small number of individuals, had control of all of the wealth of for example, the Coast Tsimshian, they could have lived in extraordinary splendor, certainly rivaling any other North American elites. Populations in some areas were sufficient for a small, well-stratified polity. The Coast Tsimshian who wintered in Prince Rupert Harbor, a small, circumscribed area, numbered some 6,000 people. The Chinookans on the south coast may have numbered over 20,000 people (Boyd 1985).

In some cases, populations were very spatially circumscribed. On the lower Columbia River, near present-day Portland, Oregon, dense human populations were tightly constrained to a small floodplain. In other instances, particular groups controlled resources or resource localities crucial to the subsistence of entire regions that could easily have been used as leverage to gain economic power over adjacent groups.

The question becomes not why did hierarchical inequality exist on the Northwest Coast at all, but why was there not more of it? Why did not a few Great Chiefs exercise power over many households. Part of the answer I think is scale. The regional and demographic scales at which Northwest Coast chiefs operated were vast. One interaction sphere (the Northern coast [Ames 1989; Suttles 1990|) minimally included Southeast Alaska, the British Columbia mainland coast, and the Queen Charlotte Islands, with a population in the early nineteenth century of some 45,000 people. ${ }^{4}$ Estimating 100 people per House, ${ }^{5}$ there were 450 Houses in the region and 450 House chiefs. This number is probably too low but the actual figure is not important. What is crucial here is that the simple number of chiefs who interacted, and the distances across which they interacted, probably made it impossible for any individual or group to dominate even some portion of the interaction sphere for very long, let alone the entire region.

The origins of the Northwest Coast elite certainly lie in the formation of large, permanent extended households around 3,000 to 3,500 years ago. I believe the original elite were the genealogical core of those early households-the people directly descended from the founder who gave the household its cross-generational continuity. Households controlled resources and competed for members. The household core originally controlled household production by controlling the House itself, and the House, as I have shown, could stand for several hundred years, but required considerable labor and skill to maintain. The household core may also have controlled some of the skills crucial to reproducing the House. This proto-elite either were labret wearers or appropriated labret wear as a marker of their emerging status. Differences in wealth and status were and remained at base differences in the wealth of households.

The use of slaves may have evolved as the chiefs' inability to exercise power over household production conflicted with their desire to reproduce themselves as an elite. From the standpoint of chiefs, the loss of household members they could not control to slave raiders was balanced by the acquisition of slaves they could control. I note above the possibility that large Houses appeared on the coast ca. 1500 b.p. The increase in mean House size after 1500 b.p. On the Northwest Coast is just the increase required to accommodate a few slaves per household (Ames i.p.). The burial record in-

'This figure is based on Boyd's (1985) estimates for the Tlingit, Haida. Tsimshian (including Coast Tsimshian, Nishga, Gitksan, and Southern Tsimshian), and Haisla. Boyd's figures are minimum estimates for the precontract populations.

'House membership could range from 20 or 30 to well over a hundred individuals. I assume 100 people here to produce a reasonable minimum estimate. 
dicates that gender and region of origin were significant dimensions of elite status. Historically, woman's labor was important in production for household consumption and for trade (Norton 1985) - the regional aspect of the Northwest Coast's household economy. Adams (1973) describes chiefs as forming a regional oligarchy, and the archaeological and ethnographic records indicate rather far-flung interaction spheres (Ames 1989).

The evolution of inequality on the Northwest Coast can only be understood at several interacting scales. The scale of the household is fundamental, but so too are the regional scales of social, political, and economic interaction. The Northwest Coast lacked stratified polities. The development of polities on the coast (and by extension anywhere else in the world) would have required a simultaneous reorganization of household and regional social and political economies by a preexisting or emerging elite. Such changes would probably have occurred swiftly, rather than over long-term transitions. A materialist approach to the evolution of inequality must account for why such transitions occur, and why they succeed or fail.

\section{ACKNOWLedgments}

I would like to thank Doug Price and Gary Feinman for the invitation to participate in the stimulating symposium on which this volume is based. Their editing significantly improved this chapter. I also want to thank Madonna Moss for her extensive comments on an earlier draft. Any errors of course are mine.

\section{REFERENCES}

Acheson, S. R., 1991, In the Wake of the ya'aats'xaatgáay [Iron People]: S Study of Changing Settlement Strategies among the Kunghit Haida, Unpublished Ph.D. dissertation, University of Oxford.

Adams, J. W., 1973, The Gitksan Potlatch, Population Flux, Resource Ownership and Recipnocity, Holt, Rinehart \& Winston, Toronto.

Adams, J. W., 1981, Recent Ethnology of the Northwest Coast, Annual Review of Antbropology 10:361-392.

Allaire, L., 1984, A Native Mental Map of Coast Tsimshian Villages, in: The Tsimsbian: Images of the Past, Views of the Present (M. Seguin, ed.), University of British Columbia Press, Vancouver, pp. 82-98.

Ames, K. M., 1981, The Evolution of Social Ranking on the Northwest Coast of North America, American Antiquity 46:789-805.

Ames, K. M., 1985, Hierarchies, Stress and Logistical Strategies among Hunter-Gatherers in Northwestern North America, in: Prebistoric Hunter Gatberers, the Emergence of Cultural Complexity (T. D. Price and J. Brown, eds.), Academic Press, New York, pp. 155-180.

Ames, K. M., 1989, Art and Regional Interaction among Affluent Foragers on the North Pacific Rim, in: Preprint Proceedings: Circumpacific Prehistory Conference, Seattle, Vol. III, Part 2, unpaginated.
Ames, K. M., 1991, The Archaeology of the Longue Duree: Temporal and Spatial Scale in the Evolution of Social Complexity on the Southern Northwest Coast, Antiquity 65:935-945.

Ames, K. M., 1994a, The Northwest Coast: Complex Hunter-Gatherers, Ecology, and Social Evolution, Annual Review of Antbropology 23:209-229.

Ames, K. M., 1994b, The Archaeology of the Northern Northwest Coast: The North Coast Prehistory Project Excavations in Prince Rupert Harbour, British Columbia, Report on file, Archaeological Survey of Canada, Ottata.

Ames, K. M., i.p., Life in the Big House, Household Labor and Dwelling Size on the Northwest Coast, in: People Who Live in Large Houses (G. Coupland, ed.), Prehistory Press, Madison. Ames, K. M., D. F. Raetz, S. Hamilton, and C. McAfee, 1992, Household Archaeology of a Southern Northwest Coast Plank House, Journal of Field Arcbaeology 19:275-290.

ARCAS (ARCAS Consulting Archaeologists, Ldd.), 1991, Arcbaeological Investigations at Tsaw wassen B.C., Report on file, B.C. Heritage Branch, Victoria.

Amold, J. E., 1991, Transformation of a Regional Economy: Sociopolitical Evolution and the Production of Valuables in Southern Califomia, Antiquity 65:953-962.

Amold, J. E., 1992, Complex Hunter-Gatherer-Fishers of Prehistoric California: Chiefs, Specialists, and Maritime Adaptations of the Channel Islands, American Antiquity 57:60-84.

Arnold, J. E., 1993, Labor and the Rise of Complex Hunter-Gatherers, Joumal of Anthropological Archaeology 12:75-119.

Bamett, H. G., 1955, The Coast Salish of British Columbia, The University Press, University of Oregon, Eugene.

Beattie, O. B., 1981, An Analysis of Prebistoric Human Skeletal Material from the Gulf of Georgia Region of British Columbia, Unpublished Ph.D. dissertation, Simon Fraser University, Burnaby.

Bender, B., 1989, The Roots of Inequality, in: Domination and Resistance (D. Miller, M. Rowlands, and C. Tilley, eds.), Unwin Hyman, London, pp. 83-92.

Boas, F., 1916, Tsimshian Mythology, Thirty-First Annual Report of the Bureau of American Ethnology 1909-1910, Government Printing Office, Washington, D.C., pp. 27-1037.

Bogucki, P., 1993, Animal Traction and Households in Neolithic Europe, Antiquity 67:492503.

Boyd, R. T., 1985, The Introduction of Infectious Diseases among the Indians of the Pacific Nortbwest, 1774-1874, Unpublished Ph.D. dissertation, University of Washington, Seattle.

Brumfiel, E. M., and Earle, T. K., 1987, Specialization, Exchange, and Complex Societies: An Introduction, in: Specialization, Exchange and Complex Societies (E. Brumfiel and T. $\mathrm{K}$ Earle, eds.), Cambridge University Press, Cambridge, pp. 1-9.

Burley, D., and Knusel, C., 1989, Burial Patterns and Archacological Interpretation: Problems in the Recognition of Ranked Society in the Coast Salish Region, in: Preprint Proceedings: Circumpacific Prehistory Conference, Seattle, Vol. III, Part 2, unpaginated.

Carlson, R. L., 1991, The Northwest Coast before A.D. 1600, in: Proceedings of the Great Ocean Conferences, Volume One the North Pacific to 1600, The Oregon Historical Society, Portland, pp. 109-137.

Chatters, J. C., 1989, The Antiquity of Economic Differentiation within Households in the Puget Sound Region, Northwest Coast, in: Housebolds and Communities (S. MacEachem, D. J. W. Archer, and R. D. Garvin, eds.), Archaeological Association of the University of Calgary, Calgary, pp. $168-178$.

Cobb, C. R., 1993, Archaeological Approaches to the Political Economy of Nonstratified Societies, in: Archaeological Method and Theory, Volume 5 (M. B. Schiffer, ed.), University of Arizona Press, Tucson, pp. 43-100

Connelly, T. J., 1992, Human Responses to Change in Coastal Geomorphology and Fauna on the Southern Northwest Coast: Archaeological Investigations at Seaside, Oregon, University of 
Oregon Antbropological Papers 45, Department of Anthropology and Oregon State Museum of Anthropology, University of Oregon, Eugene.

Costin, C. L., 1991, Craft Specialization: Issues in Defining, Documenting and Explaining the Organization of Production, in: Archaeological Metbod and Tbeory, Volume 3 (M. B. Schif fer, ed.), University of Arizona Press, Tucson, pp. 1-56.

Coupland, G., 1985, Household Variability and Status Differentiation at Kitselas Canyon, Cana. dian Joumal of Archaeology 9:39-56.

Coupland, G., 1988, Prehistoric Economic and Social Change in the Tsimshian Area, in: Reseancb in Economic Anthropology, Supp. 3 (B. Issac, ed.), JAI Press, Greenwich, pp. 211-245.

Coupland, G., i.p., The Evolution of Multi-Family Households on the Northwest Coast of North America, in: People Wbo Live in Large Houses (G. Coupland, ed.), Prehistory Press, Madison.

Coutre, A., 1975, Indian Copper Artifacts from Prince Rupert, Physical Metallungical Laborato ries Report MRP/PMRL-75-3(RR), Canada Centre for Mineral and Energy Technology, Energy and Mines Resources Canada, Ottawa, Archaeological Survey of Canada Archives Ms. No. 1079.

Cybulski, J. S., 1975, Skeletal Variation in British Columbia Coastal Populations: A Descriptive and Comparative Assessment of Cranial Morphology, National Museum of Canada Mercury Series, Archaeological Survey of Canada Paper No. 30, Ottawa.

Cybulski, J. S., 1979, Conventional and Unconventional Burial Positions at Prince Rupen Harbour, British Columbia, Archaeological Survey of Canada Archive Manuscript No. 1486.

Cybulski, J. S., 1993, A Greenville Burial Ground: Human Remains in British Columbia Coast Prebistory, Archaeological Surveyof Canada, Canadian Museum of Civilization, Ottawa

de Laguria, F., 1983, Aboriginal Tlingit Political Organization, in: The Development of Political Onganization in Native North America (E. Tooker, ed.), Proceedings of the American Ethnological Society, Washington, D.C., pp. 71-85.

Donald, L., 1983, Was Nuu-chah-nulth-aht (Nootka) Society Based on Slave Labor? in: The De velopment of Political Onganization in Native North America (E. Tooker, ed.), Proceedings of the American Ethnological Society, Washington, D.C., pp. 108-119.

Donald, L., 1985, On the Possibility of Social Class in Societies based on Fxtractive Subsistence, in: Status, Structure and Stratification: Current Arcbaeological Reconstructions (M Thompson, M. T. Garcia, and F. J. Kense, eds.), Archacological Association of the University of Calgary, Calgary, pp. 237-243.

Donald, L, and D. H. Mitchell, 1975, Some Correlates of Local Group Rank among the Southern Kwakiut, Etbnology 14:325-346.

Drucker, P., 1951, The Northern and Central Nootkan tribes, Bureau of American Etbnology, Bulletin 144, Smithsonian Institution, Washington, D.C.

Emmons, G. T., 1991, The 7lingit Indians (F. de Laguna, ed.), University of Washington Press,

Seattle.
Fladmark, K. R., 1982, An Introduction to the Prehistory of British Columbia, Canadian Joumal of Archaeology 3:131-144.

Fried, M., 1967, The Evolution of Political Society, Random House, New York.

Garfield, V., 1939, Tsimshian Clan and Society, University of Washington Publications in An thropology 7:169-340.

Gilman, A., 1981, The Development of Social Stratification in Bronze Age Europe, Cument Anthropology 22:1-23.

Guedon, M.-F., 1984, An Introduction to Tsimshian World View and Its Practitioners, in: The Tsimsbian: Images of the Past; Views for the Present (M. Seguin, ed.), University of British Columbia Press, Vancouver, pp. 137-159.

Haas, J., 1982, The Evolution of the Prebistoric State, Columbia University Press, New York. Halpin and Seguin, 1990, Tsimshian Peoples: Southern Tsimshian, Coast Tsimshian, Nise and Gitksan, in: Handbook of Nortb American Indians, Volume 7, Northwest Coast (W. Suttles, ed.), Smithsonian Institution, Washington, D.C., pp. 267-284.

Hammond, N., 1991, Inside the Black Box: Defining Maya Polity, in: Classic Maya Political History (T. P. Culbert, ed.), Cambridge University Press, Cambridge, pp. 253-284.

Hayden, B., and A. Cannon, 1982, The Corporate Group as an Archacological Unit, Joumal of Anthropological Archaeology 1:132-158.

Hastorff, C. A., 1990, One Path to the Heights: Negotiating Political Inequality in the Sausa of Peru, in: The Evolution of Political Systems; Sociopolitics in Small-Scale Sedentary Societies (S. Upham, ed.), Cambridge University Press, Cambridge, pp. 146-176.

Huelsbeck, D. R., 1989, Food Consumption, Resource Exploitation and Relationships with and between Households at Ozette, in: Housebolds and Communities (S. MacEachern, D. J. W. Archer, and R. D. Garvin, eds.), Archaeological Association of the University of Calgary, Calgary, pp. 157-166.

Kan, S., 1989, Why the Aristocrats Were "Heavy" or How Erhnopsychology Legitimized Inequality among the Tlingit, Dialectical Anthropology 14:81-94.

Kristiansen, K., 1991, Chiefdoms, States, and Systems of Social Evolution, in: Chiefdoms, Power, Economy, and Ideology (T. Earle, ed.), Cambridge University Press, Cambridge, pp. 16-43.

Maschner, H. D. G., 1991, The Emergence of Cultural Complexity on the Northern Northwest Coast, Antiquity 65:924-934.

Maschner, H. D. G., 1992, The Origins of Hunter-Gatherer Sedentism and Political Complexity: A Case Study from the Nortbern Northuest Coast, Unpublished Ph.D. dissertation, University of California, Santa Barbara.

Matson, R. G., 1976, The Glenrose Cannery Site, Archaeological Survey of Canada Paper, Mercury Series No. 52, Ottawa.

Matson, R. G., 1983, Intensification and the Development of Cultural Complexity: The Northwest versus the Northeast Coast, in: The Evolution of Maritime Cultures on the Northeast and Northwest Coasts of America (R. J. Nash, ed.), Department of Archaeology Publication No. 11, Simon Fraser University, pp. 124-148.

Matson, R. G., 1985, The Relationship between Sedentism and Status Inequalities among HunterGatherers, in: Status, Structure and Stratification: Current Archaeological Reconstructions (M. Thompson, M. T. Garcia, and F. J. Kense, eds.), Archaeological Association of the University of Calgary, Calgary, pp. 245-252.

Matson, R.G., 1989, The Locarno Beach Phase and the Origins of the Northwest Coast Ethnographic Pattern, in: Preprint Proceedings: Circumpacific Prehistory Conference, Seattle, Vol. III, Part 2, unpaginated.

Matson, R. G., 1992, The Evolution of Northwest Coast Subsistence, in: Long-Term Subsistence Change in Prehistoric North America (D. E. Croes, R. A. Hawkins, and B. L. Isaac, eds.), Research in Economic Antbropology, Supp. 6, JAI Press, Greenwich, pp. 367-430.

Mauger, J. E., 1978, Shed Roof Houses at the Ozette Archaeological Site: A Protohistoric Architectural System, Project Report Number 73, Washington Archaeological Research Center, Washington State University, Pullman.

Mitchell, D., 1983, Sebassa's Men, in: The World as Sharp as a Knife: An Antbology in Honour of Wilson Duff (D. N. Abbott, ed.), British Columbia Provincial Museum, Victoria.

Mitchell, D., 1984, Predatory Warfare, Social Status and the North Pacific Slave Trade, Ethnology 23:39-48.

litchell, D., 1985, A Demographic Profile of Northwest Coast Slavery, in: Status, Structure and Stratification: Current Archaeological Reconstructions (M. Thompson, M. T. Garcia, and F. J. Kense, eds.), Archaeological Association of the University of Calgary, Calgary, pp. 227-236.

Fitchell, D., 1988, Changing Patterns of Resources Use in the Prehistory of Queen Charlotte Strait, 
British Columbia, in: Prehistoric Economies of the Northwest Coast, Research in Economic Anthropolog, Supp. 3 (B. Issac, ed.), JAI Press, Greenwich, Connecticut, pp. 245-292

Mitchell, D., and L. Donald, 1988, Archaeology and the Study of Northwest Coast Economies, Prebistoric Economies of the Nortbwest Coast, Researcbin Economic Antbropology, Supp. 3 (B. Issac, ed.), JAI Press, Greenwich, Connecticut, pp. 293-351.

Moss, M. L., 1993, Shellfish, Gender and Status on the Northwest Coast: Reconciling Archaeological, Ethnographic, and Ethnohistoric Records of the Tlingit, American Antbropologist 95:631-652.

Moss, M. L., and J. M. Erlandson, 1992, Forts, Refuge Rocks, and Defensive Sites: The Antiquity of Warfare along the North Pacific Coast of North America, Arctic Antbropology 29:73-90.

Murray, J. S., 1981, Prehistoric Skeletons from Blue Jackets Creek (FIUa 4), Queen Charlotte Islands, British Columbia, in: Contributions to Physical Anthropology, 1979-1980, J. S. Cybulski, ed.), National Museum of Man Mercury Series, Archaeological Survey of Canada Paper 106, National Museums of Canada, Ottawa, pp. 127-168.

Norton, H. H., 1985, Women and Resources on the Northwest Coast: Documentation from the Eigbteenth and Nineteentb Centuries, Unpublished Ph.D. dissertation, University of Washington, Seattle.

Oberg, K., 1973, The Social Economy of the Tlingit Indians, University of Washington Press, Seattle

Olszewski, D. I., 1991, Social Complexity in the Natufian? Assessing the Relationship of Ideas and Data, in: Perspectives on the Past, Theoretical Biases in Mediterranean Hunter-Gatberer Researcb (G. A. Clark, ed.), University of Pennsylvania Press, Philadelphia, pp. 322-340.

Penthick, D., 1976, First Approaches to the Northwest Coast, J. J. Douglas Ltd., Vancouver.

Ray, V., 1938, Lower Chinook Ethnographic Notes, The University of Washington Publications in Antbropology 7(2):29-165.

Richardson, A., 1981, The Control of Productive Resources on the Northwest Coast of North America, in: Resource Managers: North American and Australian Hunter-Gatherers (N. Williams and E. S. Hunn, eds.), AAAS Selected Symposium No. 67.

Riches, D., 1979, Ecological Variation on the Northwest Coast: Models for the Generation of Cognatic and Matrilineal Descent, in: Social and Rcological Systems (P. Burnham and R. F. Ellen, eds.), Academic Press, New York, pp. 145-166.

Samuels, St.R., 1989, Spatial Patterns in Ozette Longhouse Middens, in: Housebolds and Communities (S. MacEachern, D. J. w. Archer, and R. D. Garvin, eds.), Archaeological Association of the University of Calgary, Calgary, pp. 143-156.

Schalk, R. F., 1977, The Structure of an Anadromous Fish Resource, in: For Theory Building in Archaeology (L. R. Binford, ed.), Academic Press, Orlando, pp. 207-249.

Service, E. R., 1975, Origins of the State and Civilization, 7he Process of Cultural Evolution, W. W. Norton, New York

Severs, P., 1974, Recent Archaeological Research at Blue Jackets Creek, FIUa 4, The Queen Charlotte Islands, The Midden 6(2):22-24.

Shane, A. P. M., 1984, Power in Their Hands: The Gitsonkt, in: The Tsimshian: Images of the Past; Views for the Present (M. Seguin, ed.), University of British Columbia Press, Vancouver, pp. 160-174.

Stearns, M. I., 1984, Succession to Chiefship in Haida Society, in: The 7simshian and Their Neighbors of the North Pacific Coast (J. Miller and C. M. Eastman, eds.), University of Washington Press, Seattle, pp. 190-219.

Suttles, W., 1951, Economic Life of the Coast Salish of Haro and Rosario Straits, Unpublished Ph.D. dissertation, University of Washington, Seattle

Suttles, W., 1968, Coping with Abundance: Subsistence on the Northwest Coast, in: Man the Hunter (R. B. Lee and I. Devore, eds.), Aldine, Chicago, pp. 56-67.

Sulles, w (ed) 1990, Handbook of Nortb American Indians, Volume 7, Nortbwest Coast, Smithsonian Institution, Washington, D.C.

Webster, G. S., 1991, Labor Control and Emergent Stratification in Prehistoric Europe, Current Anthropology 31:337-366.

Wilk, R. R., and W. L. Rathje, 1982, Household Archaeology, American Behavioral Scientist $25: 631-640$.

Wobst, H. M., 1974, Boundary Conditions for Paleolithic Social Systems: A Simulation Approach, American Antiquity 31:147-179.

Wobst, H. M., 1976, Locational Relationships in Paleolithic Society, Journal of IHuman Evolution 5:49-58.

Wolf, E R 1990, Distinguished lecture: Facing Power-Old Insights, New Questions, American Antbropologist 92:586-596.

Wooley, C. B., and J. C. Haggarty, 1989, Tlingit-Tsimshian Interaction in the Southern Alexander Archipelago, Paper presented to the 16th annual meeting of the Alaska Anthropological Association, Anchorage. 